\title{
A UNIVERSIDADE POPULAR NA PARAHYBA DO NORTE: REFLEXÕES SOBRE O DIREITO DAS MULHERES
}

\author{
Amanda Sousa Galvíncio ${ }^{1}$ \\ Maíra Lewtchuk Espindola² \\ Jean Carlo de Carvalho Costa ${ }^{3}$
}

\begin{abstract}
Resumo
As mulheres, na virada do século XIX para século XX, começaram a protagonizar o debate público brasileiro. Nísia Floresta traduziu e publicou "O Direito das Mulheres e injustiça dos Homens", em 1832, o escrito da inglesa, Mary Wollstonecraft, originalmente intitulado de "Vindication Of The Rights Of Woman", em 1792. Na Parahyba do Norte, em 1913, Catharina Moura, em conferência pública na Universidade Popular, proclamou discurso com igual título, retomando as teses defendidas pelas suas antecessoras. O objetivo desse trabalho é compreender o projeto educacional proposto pelas mulheres intelectuais que participaram do debate público, particularmente, o da Catharina Moura. As fontes utilizadas são os jornais e revistas do período que foram suporte da escrita dessas mulheres, mais especificamente, o jornal parahybano, A União. Como referencial teórico-metodológico foi utilizado a História dos Intelectuais que auxilia a compreender a trajetória, a geração e as redes de sociabilidades que atravessaram a vida dessas mulheres, bem como a participação delas e as ideias que propagavam no debate público do período. Nesse sentido, é possível concluir que as mulheres atuaram como intelectuais se posicionando em favor da emancipação feminina pela via da educação escolar e cultural. Catharina Moura fez parte da tradição de mulheres escritoras e engajadas do período, defendendo a igualdade de oportunidades entre homens e mulheres nas mais diversas profissões e também destacando a legitimidade do voto feminino.
\end{abstract}

Palavras-chave: O direito das mulheres. Mulheres intelectuais. Educação das mulheres.

\section{THE POPULAR UNIVERSITY IN PARAHYBA DO NORTE: REFLECTIONS ON THE LAW OF WOMEN}

\begin{abstract}
Women, from the turn of the nineteenth century to the twentieth century, began to play the leading role in the Brazilian public debate. Nísia Floresta translated and published "The Law of Women and the Injustice of Men" in 1832, the English writing, Mary Wollstonecraft, originally titled "Vindication of the Rights of Woman" in 1792. In Parahyba do Norte, in 1913, Catharina Moura, in a public conference at the Popular University, proclaimed a speech with the same title, retaking the theses defended by her predecessors. The purpose of this paper is to understand the educational project proposed by the women intellectuals who participated in the public debate, particularly Catharina Moura. The sources used are the
\end{abstract}




\title{
Revista HIIST'TEIDBR On-line
}

ISSN: 1676-2584

Artigo

doi: $10.20396 /$ rho.v18i1.8651670

periodicals and periodicals that were the writing support of these women, more specifically the Parahyban newspaper, A União. As a theoretical-methodological reference was used the History of Intellectuals that helps to understand the trajectory, generation and networks of sociabilities that have crossed the lives of these women, as well as the participation of them and the ideas that propagated in the public debate of the period. In this sense, it is possible to conclude that women acted as intellectuals positioning themselves in favor of female emancipation through school and cultural education. Catharina Moura was part of the tradition of women writers and engaged in the period, defending equal opportunities between men and women in the most diverse professions and also highlighting the legitimacy of the female vote.

Keywords:Women's law. Women intellectuals. Education of women.

\section{LA UNIVERSIDAD POPULAR EN PARAHYBA DO NORTE: REFLECTIONES SOBRE EL DERECHO DE LAS MUJERES}

\begin{abstract}
Resumen
Las mujeres, a la vuelta del siglo XIX al siglo XX, comenzaron a protagonizar el debate público brasileño. Nísia Floresta tradujo y publicó "El derecho de las mujeres y la injusticia de los hombres", en 1832, el escrito de la inglesa, Mary Wollstonecraft, originalmente titulado "Vindication Of The Rights Of Woman", en 1792. En la Parahyba do Norte, en 1913, Catharina Moura, en una conferencia pública en la Universidad Popular, proclamó un discurso con igual título, retomando las tesis defendidas por sus antecesoras. El objetivo de este trabajo es comprender el proyecto educativo propuesto por las mujeres intelectuales que participaron del debate público, particularmente el de la Catharina Moura. Las fuentes utilizadas son los periódicos y revistas del período que fueron soporte de la escritura de esas mujeres, más específicamente, el periódico parahybano, La Unión. Como referencial teórico-metodológico se utilizó la Historia de los Intelectuales que ayuda a comprender la trayectoria, la generación y las redes de sociabilidades que atravesaron la vida de esas mujeres, así como la participación de ellas y las ideas que propagaban en el debate público del período. En ese sentido, es posible concluir que las mujeres actuaron como intelectuales posicionándose en favor de la emancipación femenina por la vía de la educación escolar y cultural. Catharina Moura formó parte de la tradición de mujeres escritoras y comprometidas del período, defendiendo la igualdad de oportunidades entre hombres y mujeres en las más diversas profesiones y también destacando la legitimidad del voto femenino.
\end{abstract}

Palabras clave: El derecho de las mujeres. Mujeres intelectuales. Educación de las mujeres. 


\section{INTRODUÇÃO}

No Brasil, na virada do século XIX para o século XX, o feminismo assumia várias perspectivas, essas ideias começavam a ganhar espaço nos debates públicos. Pinto (2003) indica, em Uma história do Feminismo no Brasil, pelo menos, três tendências do feminismo no período aqui estudado, pensadas levando em consideração a gradação radical das suas propostas. A primeira estava marcada pela presença da sufragista Bertha Lurtz ${ }^{4}$, denominado de feminismo bem comportado, pois, não questionava as formas de opressão sofrida pelas mulheres (PINTO, 2003; OTTO, 2004). O segundo nomeado de feminismo mal comportado reunia diversas mulheres: intelectuais, anarquistas e líderes operárias. Essas, além da questão do político, defendiam o direito à educação e reconheciam a dominância masculina e questionavam, inclusive, a sexualidade e o divórcio (PINTO, 2003; OTTO, 2004). Por fim, o terceiro é chamado de o menos comportado dos feminismos, praticado pelas mulheres que se encontravam dentro do movimento anarquista e no partido comunista, teve como uma das suas principais representantes Maria Lacerda de Moura (PINTO, 2003; OTTO, 2004) ${ }^{5}$.

O lugar que a mulher deveria ocupar na sociedade estava embasado, desde abordagens positivistas e cientificistas, como foi o caso do jornal, O Sexo Feminino, no fim do século XIX. Esse periódico foi basicamente produzido por mulheres, tendo como redatora Francisca Dinis e circulou principalmente no estado de Minas Gerais, mas também existem registros desse periódico em Lorena (SP), Rio Preto (SP), além de permutas com jornais da Bahia, Pernambuco, Santa Catarina, Rio Grande do Norte, de Madrid e Nova York. O Sexo Feminino tinha como finalidade abrir espaços para as mulheres brasileiras, elevando suas condições de traste de casa, para o pedestal de rainhas do lar, que se sustentava pelo argumento positivista, em voga na época, no qual a mulher teria como função social o trinômio: religião, instrução e nação (NASCIMENTO, OLIVEIRA, 2007).

Nesse contexto, também houve ideias feministas ligadas ao movimento operário das anarquistas que começavam a tomar fôlego, especialmente, nas primeiras décadas do século XX, em São Paulo, e aglutinavam diversas mulheres: Isa Ruti, Martilde Magrassi, Maria de Oliveira, Josefina Stefani, Tibi e Maria Lacerda de Moura. Essas mulheres, sobretudo, escreveram em jornais operários do período, como: A Terra Livre, A Plebe, A Revolução Social, O Internacional e O Amigo do Povo. (RAGO, 1985; MENDES, 2008).

Ainda estiveram disponíveis, na época, os modelos de representação feminina que circulavam na literatura brasileira, seja feita por homens ou por mulheres, e como nos diz Telles (2011, p.408): “As representações literárias não são neutras, são encarnações 'textuais' da cultura que as gera”. Sobre a relação mulher e literatura, Rago (1995) investiga os modelos de representação feminina em romances, de 1900 até 1932, sobretudo, escritos por mulheres: Elisa Teixeira de Abreu, Carmem Dolores e Lola de Oliveira. Em outro momento, a mesma autora, se debruça na literatura historiográfica, dos anos 1920 e 1930, 
escrita por homens, com a intenção de problematizar a identidade brasileira feminina presentes nas obras de: Paulo Prado, Gilberto Freire, Caio Prado e Sergio Buarque de Holanda.

Duarte (2003), de modo abrangente, busca pensar os diálogos travados por mulheres na literatura, desde as primeiras publicações da escrita feminista, como Nísia Floresta, no século XIX. Duarte (2003) estabelece um marco para as reivindicações feministas no Brasil que inicia, segundo a autora, em 1830 com as reivindicações ligadas ao direito de aprender a ler e escrever, passando por outros marcos importantes e que agregam outras demandas, como os anos de 1870 e 1920, até chegar ao feminismo de 1970.

Norma Telles (2011) faz um apanhado das mulheres escritoras do século XIX, nos indicando trajetórias de figuras como: Nísia Floresta, Maria Firmina dos Reis, Júlia Lopes de Almeida, entre outras. Para Telles (2011) é possível identificar nas escritas dessas mulheres, contribuições dos envolvimentos políticos, destacando que as atuações dessas mulheres conectavam a causa feminina a questão da abolição dos escravos, participando de modo efetivo de clubes abolicionistas.

Sendo assim, argumentamos que é possível compreender as experiências de diversas mulheres brasileiras, situadas em diferentes regiões do país, no século XIX e nas primeiras décadas do século $\mathrm{XX}$, como feminismo, mesmo quando as mesmas ainda não utilizavam essa expressão para se definirem. Garcia (2011), em Breve História do Feminismo, define o termo de modo bastante abrangente, o qual se configura enquanto:

[...] a tomada de consciência das mulheres como coletivo humano, da opressão, dominação e exploração de quem foram e são objeto por parte do coletivo de homens no seio do patriarcado sob suas diferentes fases históricas, que as move em busca da liberdade de seu sexo e de todas as transformações da sociedade que sejam necessárias para este fim. (GARCIA, 2011, p. 13).

Nesse sentido, entendemos o feminismo como fenômeno que movimentou ideias, as quais atravessaram, em especial, a luta por reconhecimento de algumas mulheres nos espaços públicos, na vida política e na ciência. O feminismo também está imbricado com as questões políticas, ideológicas e históricas, nas quais as mulheres buscavam se inserir como agentes de ação política. (SCOTT, 1992; SOIHET, 2000; GARCIA, 2011). Ainda é preciso que se fale em feminismos, mesmo se tratando de séculos passados, aglutinavam identidades plurais que são atravessadas pela nacionalidade, classe social, grau de escolarização, religião, sexualidade, etnia e etc. (SCOTT, 1992; SOIHET, 2000; PINTO, 2003; CAMPOS, 2009; GARCIA, 2011).

Na Parahyba do Norte, se tratando da primeira República brasileira, os pesquisadores Machado, Nunes e Mendes (2013) atribuem pioneirismo as ideias feministas de Catharina Moura, em seu Catharina Moura e o Feminismo na Parahyba do Norte. Essa personagem 
da história local nasceu na província da Parahyba, em 1882, filha de Misael do Rego Moura e de Francisca Rodrigues Chaves Moura. Formou-se pela Escola Normal Oficial do estado, em 1902, atuou como professora de primeiras letras (ESPINDOLA, 2017) e, em 1908, se matriculou na Faculdade de Direito do Recife, obtendo o diploma de bacharel em direito no ano de 1912. No entanto, o valor dado às ideias de Catharina Moura repousa, em especial, aos temas abordados pela advogada em sua conferência, $\mathbf{O}$ Direito das Mulheres, realizada no dia 30 de março de 1913, no Teatro Santa Rosa, na capital parahyabana, sob a iniciativa da Universidade Popular. (MACHADO, NUNES, MENDES, 2013).

Nossa principal fonte de estudo é o jornal A União, criado para atender as necessidades do partido republicano, na Parahyba do Norte. Esse periódico circulou a primeira vez em 2 de fevereiro de 1893 e foi apenas no ano de 1910 que se tornou órgão oficial do estado. Em 1913, publicou na íntegra a conferência, O Direito das Mulheres, dando destaque na primeira página.

É possível verificar através d'A União ecos da recepção das ideias que circularam com os pronunciamentos de Catharina Moura, mesmo que de modo, ainda, parcial. O jornal trouxe para o público parahybano as ideias sobre o papel da mulher na sociedade, aglutinando diversos intelectuais, os quais buscavam engrossar o caldo dos debates, ora depreciando a intelectualidade feminina, através do argumento da fragilidade e inferioridade cognitiva inerente ao sexo; ora se posicionando em favor da emancipação da mulher pela educação e trabalho, mesmo que de leve ${ }^{6}$, sugerindo, nesse caso, uma posição clara do jornal e da gestão política sobre as questões femininas. (NUNES, 2006; MACHADO, NUNES, MENDES, 2013; GALVÍNCIO, COSTA, 2013).

As reflexões em torno do jornal como fonte histórica e das ideias propagadas por Catharina Moura, em sua conferência, na Universidade Popular, nos levaram a dois questionamentos iniciais: seria possível identificar um pensamento feminista na Parahyba do Norte? As ideias pronunciadas por Catharina Moura elucidavam a agenda política propostas por outras mulheres do período?

Para tanto, neste artigo, buscamos problematizar a questão intelectual e educacional das mulheres que viveram nos centros urbanos e que estavam ligadas a atividades na imprensa, como principal lócus de debate no século XIX e início do século XX. Procuramos também enfatizar a postura assumida pelas mulheres nos debates, as quais nos indicam um pensamento múltiplo, que nos descortina disputa entre as posições feministas. Ainda destacamos os debates em torno do voto feminino, sendo colocada, por algumas feministas, como a principal via de acesso e participação na vida política. Por fim, apresentamos algumas conclusões, ainda preliminares, em torno deste estudo.

\section{"UMA IDEA QUE TOMA VULTO - A PARAHYBA INSTRUÍ-SE": A UNIVERSIDADE POPULAR (1913)}


A Universidade Popular na Parahyba foi fundada em Janeiro de 1913, porém essa experiência não foi pioneira no país; Aguiar (1999) relata a existência de uma Universidade Popular instalada no Rio de Janeiro em 20 de março de 1904, no Centro Operário das Classes Operárias. Segundo Aguiar (1999) a proposta partiu do alagoano Elysio de Carvalho e teve o apoio de vários intelectuais como Manoel Bomfim, José Verissimo, Rocha Pombo, Pedro do Couto, Evaristo de Morais entre outros. Ligada ao partido operário e com forte cunho anarquista, a instituição carioca estava embasada no exemplo europeu de universidades populares, as quais foram retratadas como uma etapa para a luta da emancipação do proletariado. A Universidade carioca funcionou por cursos para as classes populares, a experiência não durou muito tempo e em outubro do mesmo ano foi anunciado a sua extinção. Aguiar (1999) observa a curta duração desse experimento, porém ressalta a “[...] importância não pelo que fez, que foi muito pouco. Mas por tudo o que a Universidade Popular poderia ter sido e feito". (AGUIAR, 1999, p. 286). E é justamente aqui que começamos nossa compreensão sobre a instituição parahybana.

Durante o governo de Castro Pinto na Parahyba, ocorreu a proposta de instalação de uma Universidade Popular, a qual funcionava no Theatro Santa Roza e teve sua primeira reunião para a organização das comissões no dia 15 de janeiro de 1913. A notícia da criação da Universidade popular parahybana foi divulgada tanto no estado do Rio de Janeiro quanto no do Paraná. No estado do Rio de Janeiro (RJ), os jornais A Epoca, O Paiz e Correio da Manhã, de 17 de janeiro de 1913, vincularam o telegrama sobre a inauguração da instituição e sobre a de Symphronio Oliveira de se fazer a universidade nos moldes italianos " [...] onde são conferencias feitas ao alcance do povo sobre assumptos indispensaveis ao conhecimento de todos. Inscreveram-se diversos oradores para esse fim [...]". (TELEGRAMMAS..., 1913b, p. 02; A PARAHYBA, 1913, p. 06; NOTICIAS..., 1913, p. 04). No jornal O imparcial de 19 de janeiro de 1913 foi divulgada a notícia da criação da Universidade Popular e da primeira conferência a ser realizada pelo pintor Aurelio de Figueiredo. (TELEGRAMMAS - INTERIOR, 1913a, p. 10). No Paraná encontramos no jornal A Republica de 20 de janeiro de 1913, a qual dizia que na Parahyba "[...] foi creada uma Universidade popular moldada pelas da Italia, afim de propagar a instrucção por meio de prelecções nas camadas proletárias." (A PARAHYBA..., 1913, p. 03).

Essas notícias mostravam a divulgação pelo país da criação da Universidade Popular no estado que deve ter ocorrido com o incentivo do governo local e da imprensa oficial, essa troca de notícias e telegramas foi muito comum nos jornais do período. O jornal local, A União, que era dirigido por Carlos Dias Fernandes ${ }^{7}$, abriu uma seção intitulada "Universidade Popular", a qual divulgava as conferências e notícias dessa instituição semanalmente. Evento esse que revela a importância atribuída à Universidade Popular pelos intelectuais e pelo estado, já que o jornal era um órgão do partido republicano. Entendemos, por conseguinte, o primeiro afastamento em comparação à proposta carioca, a Universidade 


\section{Revista HIISTESIDBR On-lime}

ISSN: 1676-2584

Artigo

doi: $10.20396 /$ rho.v18i1.8651670

Popular parahybana foi um projeto do governo e não possuía um cunho anarquista/socialista ${ }^{8}$.

Encontramos um fato mais importante nessas notícias: a proliferação dessas universidades pelo país. Achamos notícias de Universidades Populares fundadas no Rio de Janeiro em 1904, no Maranhão em 1905 e em Piracicaba no estado de São Paulo em 1908. Apesar do desapontamento de Aguiar (1999) em relação à instituição carioca, percebemos indicativos de uma movimentação de ideias dessa proposta no Brasil. Essas instituições foram criadas com vistas à disseminação da educação para o povo.

No jornal O Paiz do dia 20 de janeiro de 1913, na primeira página foi publicada uma matéria com o título "As Universidades Populares no Brasil"”. Essa iniciou com o questionamento: "Será o Brazil um terreno preparado para essas instituições, que assignalam tão curiosamente a intensidade da cultura nas democracias modernas?" (AS UNIVERSIDADES..., 1913, p. 01). Em seguida, a matéria comentou a experiência ocorrida no Rio de Janeiro, que teria sido brilhante, rápida e precária, pois: “[...] nella repercutiram as dissenções entre a teoria socialista e anarchistas". (AS UNIVERSIDADES..., 1913, p. 01). Percebemos que o jornal atribuiu a curta duração da instituição carioca ao fato dela ter se aproximado dessas teorias que foram consideradas na época perigosas. Aguiar (1999) mostra que a própria ideia de universidades populares na Europa eram fruto das teorias anarquistas e socialistas, portanto no Rio de Janeiro não ocorreu uma ligação entre a universidade e essas teorias pós a fundação da instituição, elas eram parte desde o início.

Seguindo, O Paiz escreveu sobre a notícia da fundação da universidade popular na Parahyba. Ressaltando o fato de ser uma iniciativa que partiu do governo Castro Pinto e que teria como modelo as existentes na Itália que funcionariam também com conferências "[...] sobre assumptos indispensaveis ao conhecimento de todos." (AS UNIVERSIDADES..., 1913, p. 01). Entendemos, por conseguinte, o destaque dado à instituição parahybana ser idealizada pelo governo, diferentemente da carioca que estava ligada ao Partido Operário Independente de cunho anarquista. O jornal, então concluiu que:

\footnotetext{
A experiencia só pode ser util. E o facto de aqui não teve êxito a universidade popular creada para operários trabalhados por idéias anarchistas dos paizes estrangeiros, não deve desanimar os parahybanos, como seu meio pacifico constituido de um proletario nacional, ainda livre daquelas dissenções. (AS UNIVERSIDADES..., 1913, p. 01).
}

Percebemos que apesar da saudação à iniciativa parahybana, o jornal deixava clara a necessidade de se afastar na nova instituição a teoria anarquista. Ressaltando a importância das universidades, principalmente em locais onde a instrução primária era pouco desenvolvida. Em resposta a essa matéria do dia 20 de janeiro, no jornal O Paiz, do dia 25 de janeiro de 1913, foi publicada uma carta intitulada "As Universidades Populares no Brazil” de J. da Fonseca Ferreira. 
Nela o autor inicia parabenizando o jornal pela iniciativa de vincular notícias sobre as universidades populares no Brasil. Aclamando também a experiência parahybana, Ferreira sugere que seja seguida por todos os estados, pois "[...] O povo tambem precisa se instruir, o systema de conferencias e aulas de carecter inteiramente pratico é o melhor meio de se chegar a esse fim". (FERREIRA, 1913, p. 03). E continua: "O insucesso daquella que foi creada no Rio, absolutamente não prova a inefficacia das universidades populares no Brazil, porquanto, sei de uma, fundada ha dois annos, que tem dado os melhores resultados. Quero me referir-me á universidade popular de Piracicaba [...]". (FERREIRA, 1913, p. 03). Ainda constatamos nesse documento que essa universidade possuía subvenção do estado de São Paulo, o qual doou o prédio que ela funcionava.

A educação assumia um papel amplo dentro da sociedade, não apenas vinculada à escola, mas sim a todos os espaços da sociedade. Educar o povo seria encaminhá-lo para um processo de cidadania, "[...] pois significava a construção de uma nova cultura cívica, centrada na educação (mais ampla e duradoura) e não apenas na instrução da população." (GOMES, 2009, p. 98). E foi para esse fim que foram criadas as universidades populares, a educação do povo em um sentido amplo, não só a formação de ler e escrever.

Similarmente ao que ocorreu no Rio de Janeiro, diversos intelectuais parahybanos se aliaram a ideia: Xavier Junior, Coriolano de Medeiros, Catharina Moura, João Tavares Lira, Álvaro de Carvalho, Thomaz Mindello, entre outros. Na primeira sessão da Universidade Popular foram formadas as comissões e eleita a diretoria. Nessa reunião foram decididas também as conferências que seriam ministradas. A Universidade parahybana funcionaria mediante conferências e não em forma de cursos como a carioca ${ }^{10}$. A União enumerou uma lista de 38 palestras para 1913, muitas dessas foram publicadas no dia seguinte a sua apresentação na Universidade Popular.

Os temas das conferências eram relativos às discussões travadas na sociedade da época - higiene, instrução pública, voto, imprensa etc. Não encontramos todas as conferências listadas publicadas no jornal, temos, para tal, duas explicações: a primeira é que nem todas foram realizadas e a segunda é relativa ao estado dos arquivos da FUNESC (no qual se encontram os jornais A União), muitos jornais não estão mais em condição de pesquisa e possuem vários números faltantes.

Sob o título "Instrucção primaria gratuita", A União anunciou um acordo ocorrido entre os sócios fundadores da Universidade Popular e as instituições de aulas noturnas gratuitas na capital. Convocando os envolvidos nesse tipo de ensino, conclamou o jornal:

As escolas nocturnas são especialmente destinadas ás classes proletárias que não dispõem de tempo durante o dia para frequentar.

É uma lacuna muito sensível a preencher na difusão das primeiras lettras aqui em nosso meio, a qual, graças á prestimosidade de algumas pessoas, já vai sendo sanada. 


\title{
Revista HIIST'TEIDBR On-line
}

Temos o prazer de declinar o nome da distincta professora d. Francisca Moura, que naturalmente ha de associar os seus hemeritos esforços a esse tentamen de concentração em serviço de tanta relevancia. (INSTRUCÇÃO..., 1913, p. 01).

A indicação do nome de Francisca Moura, mãe de Catharina Moura, deveu-se ao fato dela ser uma das responsáveis pelo Curso D. Ulrico destinado à alfabetização noturna das classes populares (ESPINDOLA, 2017), porém não ficou claro se a professora aceitou ou não o convite para a participação na universidade.

A inauguração da Universidade Popular ocorreu no sábado dia 25 de janeiro de 1913. A conferência de abertura, no entanto, não estava presente na lista divulgada anteriormente no jornal. Essa foi proferida pelo pintor parahybano Aurélio de Figueiredo, sob o título de "O desenho como elemento de educação popular: influencia da pintura nas civilisações antigas e modernas". A realização da conferência foi noticiada nos jornais do Rio de Janeiro:

\section{A Epoca, Correio da Manhã,O Paiz e O Imparcial.}

Catharina Moura realizou a oitava conferência no dia 30 de março de 1913. A conferência foi divulgada e comentada no jornal local, porém não encontramos nos periódicos de outros estados notas sobre ela. No jornal A União, a fala foi transcrita nos dias primeiro e dois de abril. Há uma introdução à conferência:

\begin{abstract}
A dr. ${ }^{\text {a }}$ Catharina Moura, jovem recentemente formada pela faculdade de direito de Recife, onde fez um dos cursos mais brilhantes, sahindo com approvações distinctas em todas as dezesseis cadeiras, produziu um peça scintillante, de forma e unidade scientifica, que deixou a mais duradoura e grata impressão no auditório.

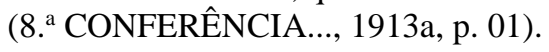

Como explicamos antes, esse jornal era dirigido no período por Carlos Dias Fernandes, colega de faculdade de Catharina Moura. Ambos ingressaram na Faculdade de Direito de Recife em 1908. Moura terminou o terceiro, o quarto e o quinto ano com distinção nos exames de todas as cadeiras. (ESPINDOLA, 2017). Em 1912, foi eleita por unanimidade a oradora da manifestação em homenagem ao Sophronio Portela - lente cathedratico da faculdade - realizada pela Faculdade de Direito em novembro do mesmo ano. (ESPINDOLA, 2017).

Terminou o curso em 1912 (laureada) e recebeu como prêmio uma viagem à Europa $^{11}$. Machado, Nunes e Mendes (2013) destacam que nesse ano formaram-se 48 bacháreis, sendo ela a única mulher, entre os parahybanos da turma estavam Carlos Dias Fernandes e Álvaro Pereira de Carvalho. Foi, também, segundo os autores, a primeira mulher parahybana a conseguir concluir uma escola superior e a primeira mulher formada na Faculdade de Direito do Recife na Primeira República. Ao se formar sua turma, incluindo Carlos Dias Fernandes, organizou uma comissão para a acompanhá-la de volta a capital parahybana: 
D'entre as manifestações promovidas pela turma actual de bacharelandos neguma mais significativa e mais affectuosa do que a que será feita a distinctissima alumna d. Catharina de Moura que termina agora o seu curso depois de um tirocinio brilhante em que conquistou as mais lisongeiras approvações e o elevado conceito em que é tida por todos os seus illustrados mestres e pelos seus dignos collegas, a par do affeto que aos mesmos soube inspirara pela maneira digna e correcta de seu procedimento e pelo seu trato ameno e fidalgo. (MOVIMENTO..., 1912, p. 02)

Podemos perceber, por conseguinte, que havia uma relação de proximidade entre Catharina Moura e Dias Fernandes. Essa afinidade foi além de uma rede de sociabilidade e de uma comunidade de experiência partilhada por ambos, mas também existiam no âmbito discursivo. Os dois intelectuais trataram de temas referentes às mulheres no próximo tópico analisamos esses discursos assim como as suas similaridades e afastamentos.

\section{MULHERES E INTELECTUAIS NA PRIMEIRA REPÚBLICA}

As primeiras iniciativas femininas de escrita e produção de jornais, no Brasil, nos remetem a primeira metade do século XIX, com destaque a tradução do livro da inglesa Mary Wollstonecraft, Vindications fon the rights woman, escrito em 1790 e traduzido por Nísia Floresta, em 1832, no Recife. Logo depois, o livro foi editado na cidade de Porto Alegre, em 1833, e ainda teve uma terceira edição no Rio de Janeiro, pela Casa do Livro Azul, que anunciava na imprensa a venda por 500 réis, no ano de 1839. (TELLES, 2011).

O Direito das Mulheres e injustiça dos Homens foi, sem dúvida, uma referência para as brasileiras escritoras. Neste trabalho, destacamos as ideias de Catharina Moura que ao proferir sua conferência, em reunião pública, reforçou o título apresentado por Nísia Floresta: O Direito das Mulheres. Isso nos faz pensar numa teia de leituras em volta dessa obra, se configurando como fio condutor na construção dos repertórios de ação política dessas mulheres. (SCOTT, 1992; ALONSO, 2002, VIEIRA, 2006; TELLES, 2011; GARCIA, 2011).

Norma Telles (2011) nos chama atenção para as relações de gênero impostas para essas primeiras escritoras brasileiras, em que a moral burguesa, de um lado, as convidava a participar do trabalho social junto ao homem, na educação dos filhos, nos trabalhos de caridade com os desvalidos, atribuindo para mulher o sentimento maternal e ser de virtude. Mas, por outro, as retiravam a possibilidade artística e intelectual. Portanto, as mulheres deveriam ser guiadas pela razão e cultura superior o qual o homem era portador. Desse modo, as mulheres eram colocadas na situação de: “[...] musa ou criatura, nunca criadora [...]". (TELLES, 2011, p. 403). Contudo, como ressalta Telles (2011) e Rago (1995), foi no ingresso do mundo das letras, no momento ainda visto como uma atividade masculina, que as mulheres encontram espaços para expor suas subjetividades, buscando driblar, através de uma linguagem própria, a sociedade que as oprimiam. 
Ou seja, nesse cenário era preciso criar estratégias e repertórios os quais fossem aceito pela sociedade, isso justifica, em certa medida, a recusa ao tom inflamado de muitas mulheres ao se pronunciarem em público. Segundo Soihet (2000, p. 98) "Algumas se rebelaram abertamente, enquanto a maioria se valia de maneiras mais sutis na ânsia de subverter sua situação. Lançavam mão de táticas que lhes permitiam reempregar os signos da dominação, marcando uma resistência".

Esse foi o caso, por exemplo, do jornal O Sexo Feminino, no século XIX, o qual esperava estrategicamente momentos históricos propícios para fazer uso de certas causas sociais, como a questão do voto e a adesão aos preceitos republicanos (NASCIMENTO, OLIVEIRA, 2007). Catharina Moura (1913a), no início do século XX, ao iniciar sua conferência recusou o jargão feminista, $\mathrm{o}$ introduzindo de modo gradual ao mesmo tempo em que fez uso da ironia para atrair a confiança dos espectadores e debochar da sociedade patriarcal:

Dizer-vos que não sou infelizmente uma feminista [...] não sou dessas mulheres admiraveis que affrontam impávidas os risos de escarneo, pesadas ironias, os malevolos dichotes com quem mimoseam os ferozes inimigos do progresso feminino, aquelles que, ou por temerem a competencia do sexo que chamam fraco ou por não querem que lhes fuja o império até aqui exercido sobre elle, lutam com o ridículo, a mais vil de todas as armas, para todo o custo conserval-o. (MOURA, 1913a, p. 01).

O feminismo foi anunciado pelo no jornal, A União, no dia 31 de março de 1913, como motivação da realização da conferência de Moura (1913a) nas reuniões da Universidade Popular:

O movimento feminista que nos grandes centros nacionais vai tendo accentuação brilhante, num esforço intellectual dos proprios elementos, pondo em evidencia o valor mental e a tempera de combatividade de muitas mulheres illustres, teve domingo um verdadeiro sucesso nesta capital [...] A' 1 1/2 hora da tarde no Theatro Santa Roza estava cheio. Pelos camarotes, repletos, viam-se famílias as mais distinctas do nosso meio, notando-se pelas galerias e cadeiras, compactas, o que esta cidade possue de mais representativo da imprensa, nas artes, na advogacia, no commercio, no magistério, etc. (UNIVERSIDADE POPULAR, 1913, p. 01).

Como dito anteriormente, a direção d'A União estava sob a responsabilidade do intelectual parahybano, Carlos D. Fernandes. A trajetória de Dias Fernandes e Catharina Moura nos indica que, entre ambos, houve a situação de micro-clima, a qual pode ser identificada pela partilha de certas subjetividades e pelo engajamento político. (SIRINELLI, 2003). As redes de sociabilidades que envolveram esses dois personagens nos remetem, inicialmente, a Faculdade de Direito do Recife, onde Moura e Dias Fernandes se formaram na mesma turma. (MACHADO, NUNES, MENDES, 2013). A Universidade Popular, instalada um ano após a formatura dos dois, nos sugere que o vínculo não havia sido quebrado. 
Outros dois episódios da história educacional parahybana acentuam esse envolvimento. O primeiro foi a Associação de Proteção aos Animais da Parahyba, fundada em 1914, tendo como idealizadora a mãe da Catharina Moura, a professora Francisca Moura. Carlos D. Fernandes foi um sujeito muito ligado à questão do direito dos animais, extrapolando sua participação na conferência de abertura, pois assumiu para si a missão de ser o Quixote dos burros, termo cunhado pelo próprio intelectual. (GALVÍNCIO, 2013). O segundo nos leva ao ano 1923, dez anos depois dos pronunciamentos de Catharina Moura, Carlos D. Fernandes preferiu a conferência, O Feminismo: emancipação da mulher pela cultura e pelo trabalho, na Escola Normal Oficial do estado, local onde Catharina Moura, desde 1917, era professora efetiva de Português e também foi responsável pelas cadeiras de desenho, francês, história da civilização, desenho linear e caligrafia. (MACHADO, NUNES, MENDES, 2013; GALVÍNCIO, 2013; ESPINDOLA, 2017).

As ideias propagadas por Carlos D. Fernandes sobre a mulher enfatizavam a função de educadora da bondade, baseadas nas concepções naturalista e humanista na qual as mulheres deveriam assumir o papel de civilizadora da nação. (ALMEIDA, 2006; GALVÍNCIO, 2013). Para Catharina Moura (1913b, p.02) as mulheres tinham plenas capacidades intelectuais, podendo exercer qualquer profissão no mundo do trabalho, mas, essa premissa não excluía a natureza materna da mulher:

\footnotetext{
Conveniente educada para o lar como para vida publica, para o sagrado aconchego da familia como para luta social ou política pela existência, poder-se-a, sem temor alargar o circulo de seus direitos, igualal-os aos do homem ampliar a sua atividade; fazer ao sexo fraco as concessões faitas ao outro sexo, sem que isto traga á sociedade ou á familia mais que incalculáveis benefícios.
}

Portanto, o discurso de Catharina Moura (1913a; 1913b) nos indica afinidades com a mulher, civilizadora da bondade, apresentada por Carlos D. Fernandes. O suporte em que as duas conferências circularam é um ponto bastante elucidativo, pois, se trata de um periódico oficial e precisava, portanto, ter coerência sobre as ideias propagadas. Além disso, se tratavam de conferências públicas e esses espaços também estavam vinculados à gestão da política local.

Essas manifestações cívicas também nos fazem pensar no público, o qual reuniu, sobretudo, as jovens da elite paraibana e normalistas, haja vista que Catharina Moura e sua mãe, Francisca Moura, eram professoras da Escola Normal da capital. Mas também pelo fato de Dias Fernandes e Catharina Moura terem feito referência enfática ao público feminino. Nesse sentido, é possível perceber que as políticas educacionais e de modernização, na Parahyaba do Norte, buscava, gradativamente, incluir uma imagem de mulher na sociedade: a intelectualizada e materna. (GALVÍNCIO, 2013).

A maternidade como atributo físico e intelectual feminino não era apenas enfatizado por Catharina Moura e Carlos D. Fernandes. Eudésia Viera, também parahybana e contemporânea de ambos, gozou de certo prestígio no cenário local ${ }^{12}$ e em seus escritos, nos 


\section{Revista HIIST'TEIDBR On-line}

Artigo

doi: 10.20396/rho.v18i1.8651670

jornais e revistas da capital, também ressaltavam a mulher como dotada de intelectualidade igual ao do homem, mas, sem que a mesma deixasse seu atributo natural: a maternidade e $o$ cuidado com a nação. Para Eudésia Viera, essas eram as funções sociais que as mulheres deveriam desempenhar na sociedade republicana. (ARAÚJO, 2003; ABRANTES, 2010).

É importante ressaltar que, na transição do século XIX para o século XX, cada vez mais, as sociedades ocidentais estavam envolvidas pela ideologia do progresso, do capitalismo e da moral burguesa, as quais também impunham para mulher a necessidade de se colocar frente ao mundo do trabalho. Com advento da República, no Brasil, os jornais depreciavam as posturas das mulheres dos períodos passados, Colônia e Império, as representando como signos de atraso: o analfabetismo, a escravidão e o latifúndio. Em relação às mulheres republicanas era enaltecida a boa educação, o interesse sincero pelo trabalho do marido, a educação dos filhos, o engrandecimento da nação e o sentimento de caridade com os desvalidos. (CAMPOS, 2009).

Essas ideias sobre as mulheres, as quais circularam nos centros urbanos do Brasil, podem ser verificadas nos jornais parahybanos e nos periódicos paulistas. Contudo, essa não era uma ideia aceitada por toda a sociedade, o que levavam muitos jornais, articuladores da opinião pública, ainda se colocarem contra a ascensão da mulher na sociedade, trazendo a figura bucólica das mulheres dos tempos passados, como sendo a verdadeira essência feminina. (CAMPOS, 2009; MACHADO, NUNES, MENDES, 2013; GALVÍNCIO, 2013; GALVÍNCIO, COSTA, 2013).

Na esteira desse argumento, se colocava em pauta como deveria ser a educação e a socialização das mulheres. A questão intelectual da mulher seria requisito ou não para o ingresso no mundo do trabalho, trazendo à tona quais funções poderiam ser ocupadas. Rago (1985) e Campos (2009) elucidam para os argumentos tratados pelos médicos e higienistas do período, os quais previam para as mulheres trabalhos diurnos e mais leve que os homens, proibindo-as do exercer ofícios noturnos. Nesse sentido, as prostitutas eram consideradas mulheres degeneradas e débeis, pois trabalhavam, essencialmente, na noite e faziam uso de bebidas alcoólicas. (RAGO, 1985).

O trabalho socialmente aceito, fora do ambiente doméstico, foi o exercício da docência. (ALMEIDA, 2006). Para Almeida (2006, p, 81-82), isso significava “[...] o trabalho intelectual e assalariado sem conotação pejorativa tinha o poder de conceder uma palavra mais abalizada num meio ignorante; conferia mobilidade social, maior liberdade e respeito entre as classes trabalhadoras e possibilitava bem-estar econômico". A relação que se constituiu em torno da feminização da profissão docente, estava consonante, como ainda ressalta Almeida (2006), com a necessidade de ampliação da escola pública no Brasil e o treinamento de profissionais para assumirem esses quadros, mas também nos indica que houve forte contribuição dos articuladores de ideias os quais, baseados nas ideias humanistas de Comenius e Rousseau, previam para a mulher o cuidado com as crianças e os desvalidos. 
Catharina Moura tratou, em sua conferência, que, além do ingresso feminino no magistério, as mulheres poderiam exercer diversas profissões: "[...] advogadas, engenheiras, as universidades estão cheias de mulheres representantes do sexo fraco desempenham os cargos de juiz de paz e outros de elevada responsabilidade". (MOURA, 1913b, p. 1-2). Nesse sentido, Moura (1913b) avançava em relação ao que era permitido socialmente para as mulheres e alargava as possibilidades de ingressos em outras profissões tidas, naquele momento, como masculinas.

Diante disso, se colocava em questão a intelectualidade feminina, tema em voga no período, e nos remete, a nosso ver, a três questões fundamentais para pensar a ação política dessas mulheres. A primeira diz respeito à questão da inferioridade cognitiva da mulher, as atribuindo uma natureza infantil e tola. Como expoente dessas ideias, as quais tiveram ampla circulação no cenário brasileiro do período, a criminologia de Lombroso e sua obra The Famele Offender (SCHUARCZ, 1993; FARIA, 2010), tratavam as mulheres como "[...] criminosas natas, criminosas ocasionais, ofensoras histéricas, criminosas de paixão, suicidas, mulheres criminosas lunáticas, epilépticas e moralmente insanas". (FARIA, 2010, p. 6).

As teorias médicas do século XIX também ressaltavam a inferioridade cognitiva da mulher, as quais ecoavam numa série de argumentos que as apresentavam como aquelas que sentem e os homens os que pensam (TELLES, 2011). Nesse sentido, na medida em que o cérebro feminino fosse se desenvolvendo, as mulheres teriam seus úteros atrofiados. (RAGO, 1985; SOIHET, 2000).

Essa querela dividia os debates sobre qual deveria ser a função social da mulher, colocando em questão se elas deveriam ou não ter acesso à educação e, mesmo se tivesse, se discutiam que tipo de educação deveria ser ofertada. Nesse sentido, a educação feminina era a grande bandeira levantada pelo coletivo de mulheres no período. (SOIHET, 2000; DUARTE, 2003; TELLES, 2011).

Nísia Floresta (apud WOLLSTONECRAFT, 1989) denunciava as ideias em torno da inferioridade cognitiva, as quais, segundo essas autoras, justificavam apenas necessidade masculina de afastar as mulheres das conquistas científicas, ocasionada pela diferença educacional dada para os sexos, colocando as mulheres em posição inferior:

Para reconhecer, pois, se as mulheres são menos capazes que os homens para as ciências, é preciso atender qual é o princípio que conduz a este conhecimento; se ele não existe na mulher, ou se existe num grau menos perfeito, não se faz necessário mais provas para demonstrar que os homens têm razão. Porém, se ele é perfeito em um como no outro, deve-se supor que homens invejosos e pode-se dizer, sem temeridade, que a única razão porque nos fecham a o caminho às ciência é temerem que nós as levamos a maior perfeição que eles. Todos sabem que a diferença dos sexos só é relativa ao corpo e não existe mais que nas partes propagadas da espécie humana [...]. Toda diferença, pois, vem da educação, do exercício e da impressão dos objetos externos, que nos cercam nas diversas circunstâncias da vida. (FLORESTA apud WOLLSTONECRAFT, 1989, p. 4647). 
Segundo Duarte (2003, p. 04), a tradução livre de Nísia Floresta foi feita com algumas modificações, as quais, além da própria Wollstonecraft, se fundamentaram nos escritos de: "[...] de Poulain de la Barre, de Sophie, e nos famosos artigos da 'Declaração dos Direitos da Mulher e da Cidadã', de Olympe de Gouges [...]". Dessa forma, corroboramos a Duarte (2003) quando anuncia que as ideias de Nísia Floresta apresentadas, em Direitos das Mulheres e injustiças dos homens, deve ser compreendida não como uma cópia da obra inglesa, mas, Nísia Floresta ao se colocar "[...] em pé de igualdade com a Wollstonecraft e o pensamento europeu, e cumprindo o importante papel de elo entre as idéias estrangeiras e a realidade nacional" (DUARTE, 2003, p.04), exerceu plenamente sua capacidade crítica, contribuindo decisivamente para a conformação das ideias feministas no Brasil. (DUARTE, 2003; TELLES, 2011).

Catharina Moura (1913b, p. 2) também provocou o seu público ao tratar das teorias que inferiorizava o intelecto feminino:

\begin{abstract}
Se há realmente uma inferioridade psychica esta será consequência da inferioridade physiologica ou será o reflexo da inferioridade social a que tem sido a mulher condemnada, isto é, a consequência da atrophia resultante da oppressão hereditária? Acreditaremos que a inferioridade cerebral da mulher é causa physiologicamente provada. Todos os traçados, todos quadros comparativos feitos entre os cérebros masculinos e feminino têm mostrado claramente que o volume cerebral da mulher é em cada um dos períodos da existência e durante toda Ella inferior ao volume cerebral do homem. Acreditamos também que essa inferioridade physiologica dê origem á inferioridade phychica. Pobre ser escravisado desde os tempos primitivos como não atrophiar-se, como evoluir? Não há quem ignore que a instrucção da mulher ainda hoje em quase toda a parte, acanhada, rudimentar, imperfeíssima, foi quase nulla até bem poucos annos.
\end{abstract}

Na esteira desses argumentos que Catharina Moura (1913b) buscava dialogar com as conquistas femininas que estavam ocorrendo em outros países, sugerindo estar atenta aos impactos ocasionados pelo movimento. Moura (1913b) afirmava que seus conhecimentos condiziam com os jornais e livros, os quais the traziam as notícias sobre os progressos ocasionados pela emancipação política da mulher em outras nações, desmentido, dessa forma, a baixa intelectualidade da mulher.

A discussão se seguiu corroborava as teses do período, em que a educação seria a forma de redenção nacional (BOTELHO, 2002). Isto é, se, por um lado, a diferença era a educação dada para ambos os sexos, por outro, seria através dela que se diluiria a desigualdade entre homens e mulheres.

A retomada dessa problemática, pelas sufragistas do século XX, como Catharina Moura, nos sugere que tais argumentos ainda se encontravam presentes na sociedade republicana, sendo o primeiro desafio a ser vencido para se obter a participação políticas das mulheres. Moura (1913b) anunciava que, no futuro próximo, era preciso o reconhecimento da cidadania feminina pelos homens: 


\section{Revista HIIST'TEIDBR On-line}

ISSN: 1676-2584

Artigo

doi: $10.20396 /$ rho.v18i1.8651670

Felizmente, para a mulher futura, a enfesada e achaica theoria da inferioridade feminina tem encontrado em campo opposto, em terreno adversário fortíssimo campeões, grandes adeptos do valor da mulher e da sua elevação social, verdadeiros enthusiastas do feminismo, se nõa do feminismo irreflectido e tolo que abraça o amor livre e outras idéas de igual monta, mas do feminismo elevado e nobre, que procura erguer a esphera social da mulher, levanatado-a, dignificando-a, arrancando-a, custe o que custar, ao humilde protectorado do sexo forte. (MOURA, 1913b, p.1).

Nessa citação, podemos destacar dois pontos centrais. O primeiro reitera as palavras de Nísia Floresta, como temos anunciado anteriormente, colocando Moura (1913b) na esteira do pensamento feminista brasileiro. A segunda, mais uma vez, reforça o envolvimento de Catharina Moura com o movimento, como representante e formadora dessas ideias em âmbito local.

Como desdobramento do último aspecto, considerando que o feminismo não pode ser caracterizado a partir de ideias homogêneas e está também implicado pelo jogo político de quem os representa. (SCOTT, 1992; PINTO, 2003; CAMPOS, 2009; GARCIA, 2011). O repertório adotado por Catharina Moura (1913a; 1913b) nos indica sua posição política frente ao movimento, pois, ela não falava de qualquer feminismo, mas do que julgava ser verdadeiro.

Vinte anos depois desses pronunciamentos, a ideia que havia um pensamento feminista no estado, com a fundação da Associação do Progresso Feminino da Parahyba, em 1933, vai ganhando consistência. Meira (1934 apud FRAGOSO, 2011), na página Feminina pertencente também ao jornal, A União, definiu o feminismo parahybano como dotado de um pensamento próprio: "O nosso é brasileiro, ou melhor, paraibano, pois afinal de contas temos nossas próprias, que se coadunam com os problemas sociais da região e não precisamos copiar de ninguém [...]”. (MEIRA, 1934, p. 11 apud FRAGOSO, 2011, p. 96).

Ou seja, pode-se pensar que a posição dessas mulheres nos debates públicos, apesar do grau evidente de pertencimento ao núcleo comum, a elevação da condição feminina na sociedade, eram encarados de modo a caracterizar a adesão a determinados grupos de reivindicações feministas. Portanto, ainda é preciso consideramos às nuances de seus repertórios.

Catharina Moura (1913a; 1913b) quando disse não fazer parte do feminismo que exaltava o amor livre, claramente, estava tomando uma posição em relação ao feminismo propagado pelas mulheres socialistas e anarquistas, que viam na relação livre a única forma de não tornar a união conjugal a escravidão da mulher, no qual o marido se tornava o patrão. (RAGO, 1985; MENDES, 2008).

Segundo Rago (1985), o amor livre era muito discutido nas rodas intelectuais dos operários, na virada do século XIX para o século XX, e, de certa forma, funcionava como o movimento contracultura das relações amorosas estabelecidas pela sociedade burguesa. $\mathrm{O}$ 
referido tema recebeu, através dos escritos e das conferências realizadas pela professora Maria Lacerda de Moura, grande propagação nas primeiras décadas do século XX: "Deixem o amor livre, absolutamente livre. Homens e mulheres encontrarão, nas leis biológicas e nas necessidades afetivas e espirituais, o seu caminho, a sua verdade e a sua vida... A solução só pode ser individual. Cada qual ama como pode [...]". (MOURA, 1932, apud RAGO, p. 128, 1985).

Nesse sentido, é que Campos (2009) nos chama atenção para as relações de classe que atravessavam a defesa de um tipo de feminismo em detrimento de outros. As feministas ligadas às elites não conseguiram, com exceção das abolicionistas, liderar grandes projetos sociais que envolvessem efetivamente a participação das mulheres pobres e operárias: "A postura dessas dirigentes era paternalista porque elas se apresentavam como porta-vozes das brasileiras menos privilegiadas, sem, no entanto, apoiar táticas de confrontação direta ou mesmo chamá-las para falarem por si mesmas". (CAMPOS, 2009, p. 125).

A querela entre as feministas cindiu a luta de duas figuras importantes para o movimento do início do século XX, Bertha Lutz e Maria Lacerda de Moura. Em 1918, estavam juntas na fundação da Liga pela Emancipação da Mulher e, em 1921, também criaram a Federação Internacional Feminina. Entretanto, essa aproximação foi rompida, em 1922, quando Maria Lacerda exonerou-se da presidência da última associação mencionada, acusando o feminismo sufragista, liderado por Bertha Lustz, de apenas reunir mulheres de classe média com a intenção de praticar filantropia. (MENDES, 2008).

A segunda questão que se coloca, em relação à inferioridade intelectual feminina, corresponde à mobilização política pelo qual essas mulheres se organizaram na vida pública. Ou seja, na medida em que essas mulheres se deslocaram da vida doméstica, prescrita pela sociedade patriarcal, e se identificavam como um coletivo organizado de reivindicações e, portanto, de ação política, podem ser identificadas como intelectuais. (VIEIRA, 2006). Mais especificamente, procuramos pensá-las como intelectuais da educação, haja vista que a elevação da condição feminina, mesmo com a pluralidade de feminismos da época, apontava para a educação como caminho de emancipação e da equidade das diferenças de gênero. (VIEIRA, 2006; FARIA FILHO, CHAMON, INÁCIO, 2009). Além disso, as mulheres citadas neste trabalho eram também professoras, nos indicando a forte ligação que elas tinham com o universo educacional de sua época.

Desse modo, é possível definir Nisia Floresta, Catharina Moura, Bertha Lutz, Maria Lacerda de Moura, entre outras mulheres, inscritas no debate público, como sujeito coletivo em ação na esfera pública, os quais abraçaram e alçaram a educação como uma preocupação política de primeira grandeza (VIEIRA, 2006; FARIA FILHO, CHAMON, INÁCIO, 2009). Ainda sobre a importância da educação, Catharina Moura (1913b, p.1) argumentou a favor de:

Eduque-se o ser humano sem distinção de sexo, faça-se com que mulher adquira aptidão legal e intellectual para o exercício de toda e qualquer profissão, de modo 
a pólo em pratica, sendo esse exercício necessário ou não havendo um impedimento material ou moral que a prive delle. Dê-se-lhe a aptidão necessária ao exercício de qualquer profissão; deixe-se que por si só escolha aquellas funções que mais possam aprazer á sua natureza, tendo porem plena capacidade legal para o exercício de quaesquer funcções da vida social e política.

A educação seria a prerrogativa para que as mulheres, devidamente instruídas, pudessem ingressar no mundo do trabalho e na vida política. Desse modo, gozaria das mesmas prerrogativas que os homens, sendo possível que elas se afirmassem não só como musas ou criaturas, mas, como criadoras. (TELLES, 2011).

A conferência de Catharina Moura (1913a; 1913b), apresentada ao público parahybano com o intuído de promover a elevação da condição feminina, marcava por parte do estado, através das instituições oficias - imprensa, Universidade Popular, Escola Normal e IHGP -, adesão à causa feminista. Mas também nos indica que o poder público, ao criar espaços para o debate, incentivando as mulheres a se inserirem na vida pública, da política, das letras e da educação, conformava uma posição feminista oficial, cuja articulação ficou a cargo de intelectuais mulheres ligadas a política republicana local.

Nesse ponto, concordamos com os autores Machado, Nunes e Mendes (2013), quanto à questão do discurso inaugural de Catharina Moura. Sua conferência, na Universidade Popular, abriu caminho para o engajamento de muitas parahybanas na luta pela partição política da mulher, em especial, se tratando do voto. As ideias anunciadas por Moura (1913a; 1913b) desembocaram na fundação da Associação pelo Progresso Feminino da Parahyba, onde também participou como fundadora. (FRAGOSO, 2011; MACHADO, NUNES, MENDES, 2013).

Contudo, acreditamos que ainda seja precipitado tomar Catharina Moura como a marco inicial do pensamento feminista no estado. Norma Telles (2011), por exemplo, faz menção ao um coletivo de 120 mulheres parahybanas, as quais, no ano da independência do Brasil, publicaram no jornal, Sentinela da Liberdade, de Cipriano Barata, “[...] como 'metade da sociedade humana' que eram, desejavam reassumir os direitos que lhes haviam sido usurpado e '[...] quebrar os vergonhosos ferros da vil escravidão em jazíamos'. Por direito, dizem, querem entrar na partilha e glória do Brasil". (TELLES, 2011, p 404-405) ${ }^{13}$. A pesquisa desenvolvida por Bezerril e Godoy (2012) também nos remontam a participação feminina nos jornais parahybanos do século XIX. Essas mulheres se associavam as questões abolicionistas e buscavam, através dos seus escritos, espaços para reivindicação de direito políticos.

Diante disso, é possível perceber que, na Parahyba do Norte, as questões das mulheres estavam sendo colocado anteriormente ao discurso de Catharina Moura. Entretanto, não retira desse personagem sua importância histórica para o estado e para o pensamento feminista na Primeira República brasileira. 
A terceira e última questão, sobre a inferioridade intelectual da mulher, que abordamos neste artigo, se refere à capacidade dela exercer sua cidadania através do voto. As reivindicações do sufrágio feminino se justificavam no princípio republicano de participação e representação política. Os jornais anunciavam a República que não foi trazendo à baila que o regime republicano não conseguiu incluir o povo na nova forma de governo. (CARVALHO, 1987; 2011).

$\mathrm{O}$ argumento estava ligado às propostas que passavam pela justificativa da "[...] exigência da incorporação do povo à nação; e a da insuficiência do povo para o exercício da cidadania [...]”. (ROCHA, 2004, p. 18). Ou seja, o primeiro julgava que a República deveria promover a emancipação da população e o segundo apontava para impossibilidade dos segmentos populares, entre esses também se encontrava as mulheres, participarem das decisões na esfera pública.

Essa estrutura de oportunidade (ALONSO, 2002) abriu caminhos para que as mulheres, mais uma vez, ocupassem a cena pública, buscando requerer seus direitos de participação política, nesse momento, sob a bandeira do sufragismo. (SOIHET, 2000; CAMPOS, 2009). Catharina Moura (1913b, p.2) anterior à notoriedade que ganharia a intelectual, Bertha Lurtz, com as campanhas em âmbito nacional em favor do voto feminino, anunciava, na Parahyba do Norte, sua crítica:

\begin{abstract}
Os direitos da mulher são, para nós brazileiros, assumpto meramente theorico, puramente doutrinário. Nossa legislação não concede á mulher capacidade para votar, não a considera hábil para eleger e ser eleita. Empregando, porem, a expressão nossa legislação, parece-me, não andei muito acertadamente. Nossa lei básica, a Constituição de 24 de fevereiro, estatuindo no seu Tit, IV, Seccão I, artigo 69 e 70, as qualidades necessárias para ser cidadão brazileiro e eleitor, não se refere ao sexo como provando que este não pode ser absolutamente considerado motivo justo de capacidade ou incapacidade physica ou moral para livre exercício do direito de voto. Donde nasce, portanto, a incapacidade da mulher se a constituição não priva do voto em nenhum de seus artigos?
\end{abstract}

Para Moura (1913b), a exclusão das mulheres na cena política, não se verificava pela sua inferioridade intelectual e física, como anunciado anteriormente, nem tão pouco podia se basear nos princípios republicanos adotados desde aquela lei. Mas, repousava na dificuldade que certos homens tinham de abrir mão do domínio sobre as mulheres. Catharina Moura (1913b, p. 1) reiterava:

[...] é evidente que a lei básica não nega á mulher o direito de voto politico. Claro está que essa privação nasce exclusivamente do arbítrio dos interpretes da nossa lei, quando não o for da ignorância que induz á crença absurda de que a mulher do lar domestico desaparecerá no dia em que surgir a mulher política ${ }^{14}$.

A tática, como prefere adotar Soihet (2000) para pensar o posicionando feminino sufragista, conciliava a mulher pública e do lar. Contudo, ao reproduzir os estereótipos de feminilidade, as mulheres também contribuíram para a desigualdade de gênero, de modo que 
a barganha entre a mulher materna, bondosa e caridosa, não entrava em choque com a mulher racional, pública e política. Nesse sentido, se nos espaços públicos as mulheres almejavam igualdade, na vida privada elas reproduziam os papeis masculinos e femininos préestabelecidos. (CAMPOS, 2009).

Por um lado, concordamos com Soihet (2000) e Fragoso (2011) quando falam das conquistas feministas desse período, as quais foram muito mais além do que as cartilhas liberais e burguesas previam para mulheres. Denotar esse grupo de bem comportado, como fez Pinto (2003), reduz a ação política dessas mulheres. Nesse sentido, em pesquisa anterior, procuramos adotar a ideia de feminismo conciliador, o qual busca compreender as contradições no pensamento dessas mulheres, ao mesmo tempo indicando as contribuições emancipadoras do movimento. (GALVÍNCIO, 2013; GALVÍNCIO, COSTA, 2013).

Contudo, não concordamos que conferir a conciliação como sendo o feminismo possível, como pretendeu Fragoso (2011). Acreditamos que essa interpretação termina por anular a reprodução das desigualdades de gênero, também presente no pensamento feminista oficial e conciliador. Pensar desse modo seria não conferir as mulheres à capacidade de mobilizar, por si mesmas, seus repertórios de ação política. (ALONSO, 2002). Para nós, o feminismo parahybano, abordado neste estudo, foi constituído por tomadas de decisões conscientes, pelo enfretamento da inferioridade feminina e desbravamento dos lugares estabelecidos para a mulher na vida pública e política, mas também reforçavam os atributos naturalizados como femininos. Nessa barganha política as mulheres marcavam suas diferenças no bojo do pensamento feminista, que se configurava no Brasil e também em outros países.

Nesse sentido, Soihet (2000, p.23, grifo do autor) nos chama atenção para as ideias de Maria Lacerda de Moura, representante das ideias radicais, as quais circulavam naquele momento:

Tal diversidade de posições revela a flexibilidade da 'jaula', representada pela cultura, possibilitando aos agentes sociais o exercício de uma relativa liberdade, conforme a articulação que estabeleçam dos elementos historicamente à sua disposição. O que é sumamente confortador!

Ou seja, havia uma mobilização de repertórios em detrimento de outros, as mulheres ao se lançarem na vida pública, requerendo direitos políticos, o faziam representando interesses dos grupos os quais estavam associadas.

\section{CONCLUSÕES}

As ideias feministas, no Brasil, ganharam entonação nos debates através da imprensa do século XIX e início do século XX. As mulheres que atuaram nesse período, ascriadoras, 
podem ser pensadas como agentes que se movimentaram na esfera pública em ação política contra a sociedade que as oprimiam. (SOIHET, 2000; TELLES, 2011). Os jornais, veículo principal da palavra impressa nesse momento histórico, cumpriam o papel de promover a opinião pública em torno da função social das mulheres. (SOIHET, 2000; MOREL, BARROS, 2003; CAMPOS, 2009; MOREL, 2011). Nesse sentido, ao utilizá-los como fontes, podemos observar de que modo às problemáticas em questão circularam e encarnaram as posições dos sujeitos envolvidos. A mobilização dos repertórios femininos, pelas intelectuais, nos sugere que havia, entre suas reivindicações, posicionamento crítico e grau de aproximação e pertencimentos a determinadas bandeiras feministas.

Na Parahyba do Norte, se tratando de Catharina Moura e das intelectuais que atuaram até a fundação da Associação pelo Progresso Feminino (1933), foi possível identificar um pensamento feminista oficial, que ganhou voz, em especial, através do jornal, A União. Essas ideias se conectavam, em certo grau, com as representadas pelo coletivo de mulheres ligadas a bandeira sufragista de Bertha Lurtz. (SOIHET, 2000; CAMPOS, 2009). É preciso pensar o feminismo parahybano para além da mediação das discussões em âmbito nacional, para não reduzimos a atuação dessas mulheres, as quais buscaram se atribuir pensamento próprio, mesmo quando se aproximavam dos diálogos travados no eixo sul e sudeste. (FRAGOSO, 2011).

Por fim, destacamos a necessidade de maior aprofundamento sobre a temática, em espacial, no que tange dois aspectos que precisarão ser mais bem explorados em estudos futuros. Desse modo, indicamos a necessidade de retomar a atuação das mulheres parahybanas no século XIX, apontadas nos estudos de Telles (2011) e Bezerril e Godoy (2012), e ampliar as fontes, indo além do discurso oficial, buscando perceber o envolvimento de outros sujeitos no debate.

\section{REFERÊNCIAS}

$8^{\circ}$ CONFERÊNCIA. Os Direitos da Mulher. Pela Dra. Catharina Moura. A União, Parahyba, ano XXI, n. 71, 01 abr. 1913a, p. 01.

$8^{\circ}$ CONFERÊNCIA. Continua. Universidade Popular. $8^{\circ}$ Conferência. Os Direitos da Mulher. A União, Parahyba, ano XXI, n. 72, 02 abr. 1913b, p. 01.

A PARAHYBA crea uma Universidade popular. A Republica, orgam do Partido Republicano Paranaense, Curytiba, n. 16, 20 jan. 1913, p. 03. Disponível em: < http://memoria.bn.br/DOCREADER/DOCREADER.ASPX?BIB=xx0719>. Acesso em: 24 jun. 2014.

AS UNIVERSIDADES Populares no Brasil. O Paiz, Rio de Janeiro, anno XXVIII, $\mathrm{n}$. 1033320, 20 jan. 1913. Disponível em: < http://memoria.bn.br/ DOCREADER/>. Acesso em: 12 ago. 2014. 
ABRANTES, A. Escritas e inscritas: mulheres na imprensa dos anos 1920. In:

ABRANTES, A.; SANTOS NETO, M. G. dos. (Org.). Outras Histórias: cultura e poder na Paraíba (1889-1930). João Pessoa: Universitária; UFPB, 2010.

AGUIAR, R. C. O rebelde esquecido. Tempo, vida e obra de Manoel Bomfim. Rio de Janeiro: Topbooks, 1999.

ALMEIDA, J. S. de. Mulheres na educação: missão, vocação e destino? A feminização do magistério ao longo do século XX. In: SAVIANI, D.; et al. (Org.). O legado educacional do século XX no Brasil. Campinas: Autores Associados, 2006.

ALONSO, Â. Idéias em movimento: a geração 1870 na crise do Brasil-Império. São Paulo: Paz e Terra, 2002.

ARAÚJO, R. C. A educação histórica e as mulheres na Paraíba: as intelectuais do IHGP (1934-1979). In: CARVALHO, M. E. P. de.; PEREIRA, M. Z. da. C. (Org.).Gênero e educação: múltiplas faces. João Pessoa: Ed. da UFPB, 2003.

BEZERRIL, F. D. de. F.; GODOY, J. H. A. de. Vozes Femininos: reivindicações das mulheres nortistas nos jornais do século XIX. In: SEMINÁRIO NACIONAL DE SOCIOLOGIA \&POLÍTICA: PLURALIDADE E GARANTIA DOS DIREITOS POLÍTICOS HUMANOS XXI, 19., 4, 2012, Curitiba, PR. Anais... Curitiba, 2012. CDROM.

BOTELHO, A. Aprendizado do Brasil. A nação em busca dos seus portadores sociais. Campinas: Ed. da Unicamp, 2002.

CAMPOS, R. D. de. Mulheres e crianças na imprensa paulista (1920-1940): educação e história. São Paulo: Ed. da UNESP, 2009.

CARULA, K. Darwinismo, raça e gênero: conferências e cursos públicos no Rio de Janeiro (1870-1889). 2012. Tese (Doutorado em História) - Universidade de São Paulo, São Paulo, 2012.

CARVALHO, J. M. de. A formação das almas: o imaginário da República no Brasil. São Paulo: Companhia das Letras, 2011.

CARVALHO, J. M. de. Os bestializados: o Rio de Janeiro e a República que não foi. São Paulo: Companhia da Letras, 1987.

COSTA, J. C. de. C.; GALVÍNCIO, A. S.; ESPINDOLA, M. L. Redes de sociabilidade e educação: atuação de Castro Pinto e Carlos Dias Fernandes na Primeira República. Revista HISTEDBR On-line, Campinas, n. 53, v. 13, p. 56-77, out. 2013.

DUARTE, C. L. Feminismo e literatura no Brasil. Estudos Avançados, São Paulo, v. 17, n. 49, 2003. Disponível: <http://www.scielo.br/scielo.php?pid=S010340142003000300010\&script=sci_arttext >. Acesso em: 11 abr. 2013. 
ESPINDOLA, M. L. As experiências dos intelectuais no processo de escolarização primária na Parahyba (1824-1922). 2017. Tese (Doutorado em Educação) - Universidade Federal da Paraíba, João Pessoa, 2017.

ESPINDOLA, M. L. Primeira República, intelectuais e educação: entre a utopia e o (des)encantamento de Castro Pinto (1888-1915). 2012. Dissertação (Mestrado em Educação) - Universidade Federal da Paraíba, João Pessoa, 2012.

FARIA FILHO, L. M. de.; INÁCIO, M. S.; CHAMON, C. S. Apresentação. FARIA FILHO, L. M. de.; INÁCIO, M. S. (Org.). Políticos, literatos, professoras, intelectuais. O debate público sobre educação em Minas Gerais. Belo Horizonte: Mazza, 2009. p. 7-20.

FARIA, T. D. A mulher e a criminologia: relações e paralelos entre a história da criminologia e a história da mulher no Brasil. In: ENCONTRO NACIONAL DO CONPEDI, 19, 2010, Fortaliza, CE, Anais... Fortaleza, 2010, p. 01-14.CD-ROM.

FERREIRA, J. da. F. As Universidades Populares no Brazil. O Paiz, Rio de Janeiro, anno XXVIII, n. 10338, 25 jan. 1913, p. 03. Disponível em:<

http://memoria.bn.br/DocReader/>. Acesso em: 12 ago. 2014.

FRAGOSO, V. de. S. Associação paraibana pelo progresso feminino: as contribuições educacionais para mulher paraibana (1933 a 1939). Dissertação (Mestrado em Educação) - Universidade Federal da Paraíba, João Pessoa, 2011.

FREITAS, A. G. B. de. Abolição e emancipação: ecos de vozes femininas no Nordeste brasileiro na passagem do século XIX para o século XX. In: CURY, C. E.; MARIANO, S. (Org.). Múltiplas Visões: cultura histórica nos oitocentos. João Pessoa: Universitária UFPB, 2009.

GALVÍNCIO, A. S. Atuação Educacional de Carlos Dias Fernandes na Parahyba do Norte (1913-1925): jornalismo, literatura e conferências. 2013. Dissertação (Mestrado em Educação) - Universidade Federal da Paraíba, João Pessoa, 2013.

GALVÍNCIO, A. S.; COSTA, J. de. C. C. As ideias feministas no jornal A União (19131920). In: SEMINÁRIO NACIONAL GÊNERO E PRÁTICA CULTURAIS

SUBJETIVIDADES E CONTRADISCURSO, 4., 2013, João Pessoa, PB. Anais... João Pessoa, 2013. CD-ROM.

GARCIA, C. C. Breve história do feminismo. São Paulo: Claridade, 2011.

GOMES, Â. de. C. A República, a história e o IHGB. Belo Horizonte: Argvmentvm, 2009.

INSTRUCÇÃO primaria gratuita. A União, Parahyba, anno XXVI, n. 18, 25 jan. 1913, p. 01. 
MACHADO, C. J. dos. S.; NUNES, M. da. S.; MENDES, M. C. F. Catharina Moura e o feminismo na Parahyba do Norte. Fortaleza: Ed. da UFC, 2013.

MENDES, S. C. O feminismo no anarquismo: as mulheres anarquistas em São Paulo na Primeira República (1889-1930). In: ENCONTRO REGIONAL DE HISTÓRIA: PODER, VIOLÊNCIA E EXCLUSÃO, 19., 2008, São Paulo. Anais ... São Paulo, 2008. CD-ROM.

MOREL, M.; BARROS, M. M. de. Palavra, imagem e poder: o surgimento da imprensa no Brasil do século XIX. Rio de Janeiro: DP\&A, 2003.

MOREL, M. Os primeiros passos da palavra imprensa. In: MARTINS, A. L.; LUCA, T. R. de. (Org.).História da Imprensa no Brasil. São Paulo: Contexto, 2011.

MOURA, C. Continua. Universidade Popular. $8^{\circ}$ Conferência. Os Direitos da Mulher. Jornal A União, Parahyba, 2 abr. 1913a.

MOURA, C. Universidade Popular. $8^{\circ}$ Conferência. Os Direitos da Mulher. Jornal A União, Parahyba, 1 abr. 1913b.

MOVIMENTO escolar. Jornal do Recife, Recife, anno 55, n. 324quarta-feira, 25 set. 1912, p. 02. Disponível em: < http://memoria.bn.br/ DOCREADER/>. Acesso em: 12 ago. 2014.

NASCIMENTO, C. V. do.; OLIVEIRA, B. J. O Sexo Feminino em Campanha pela emancipação da mulher. Cad. Pagu, n. 29, p.429-457, dez 2007. Disponível em: <http://www.scielo.br/pdf/cpa/n29/a17n29.pdf.>. Acesso em: 10 ago. 2013.

NOTICIAS da Parahyba. Correio da Manhã, Rio de Janeiro, anno XII, n. 5100, 17 jan. 1913, p. 04.

NUNES, M. L. da. S. A imprensa paraibana e os direitos da mulher: textos publicados no jornal A União na década de 1920. In: MACHADO, C. J. dos. S.; SCOCUGLIA, A. C. (Org.). Pesquisa e historiografia da educação brasileira. Campinas: Autores Associados, 2006.

OTTO, C. O feminismo no Brasil: suas múltiplas faces (Resenha). Revista Estudos Feministas, Florianópolis, v. 12, n.2, 2004. Disponível em:

<http://www.scielo.br/scielo.php?script=sci_arttext\&pid=S0104-026X2004000200015>. Acesso em: 10 abr. 2013.

PARAHYBA. O Paiz, Rio de Janeiro, n. 10330, anno XXVIII, 17 jan. 1913. p. 06.

PINTO, C. R. J. Uma história do feminismo no Brasil. Fundação Perseu Abramo, 2003.

RAGO, L. M. A subjetividade feminina entre o desejo e norma. Revista Brasileira de História, Campinas, n. 2, 1995. APNPUH, Marco Zero. Disponível em: <http://webcache.googleusercontent.com/search?q=cache:RV-162 
nSJwgz5gJ:www.anpuh.org/arquivo/download\%3FID_ARQUIVO\%3D3756+A+subjetivi dade+feminina+entre $+\mathrm{o}+$ desejo+e+norma $\& \mathrm{~cd}=1 \& \mathrm{hl}=\mathrm{pt}-\mathrm{BR} \& \mathrm{ct}=\mathrm{clnk} \& \mathrm{gl}=\mathrm{br}>$. Acesso em: 12 abr. 2013.

RAGO, L. M. Do cabaré ao lar: a utopia da cidade disciplinas. Rio de Janeiro: Paz e Terra, 1985.

RAGO, L. M. Sexualidade e identidade na historiografia brasileira. Revista Aulas, Campinas, n. 2, 2006. Disponível em: <

http://www.unicamp.br/ aulas/volume02/pdfs/sexualidade_2.pdf >. Acesso em: 12 abr. 2013.

ROCHA, M. B. M. Matrizes da modernidade republicana. Campinas: Autores Associados, 2004.

SCHUARCZ, L. M. O Espetáculo das raças: cientistas, instituições e questão racial no Brasil (1870-1930). São Paulo: Companhia das Letras, 1993.

SCOTT, J. História das mulheres. In: BURKE, P. (Org.). A escrita da história: novas perspectivas. Tradução Magda Lopes. São Paulo: Ed. da UNESP, 1992.

SIRINELLI, J. Os Intelectuais. In: RÉMOND, R. (Org.). Por uma história política. Tradução Dora Rocha. Rio de Janeiro: Ed. da FGV, 2003.

SOIHET, R. A pedagogia da conquista do espaço público pelas mulheres e a militância feminista de Bertha Lutz. Revista Brasileira de Educação, n. 15, 2000. Disponível em: < http://www.scielo.br/pdf/rbedu/n15/n15a07 >. Acesso em: 05 jan. 2014.

TELLES, N. Escritoras, escritas, escrituras. In: PRIORE, M. D.; PINSKY, C. B. (Org.). História das mulheres no Brasil. São Paulo: Contexto, 2011.

TELEGRAMMAS - Interior. O imparcial, diário ilustrado do Rio de Janeiro, Rio de Janeiro, anno II, n. 47, 19 jan.1913a, p. 10. Disponível em: < http://memoria.bn.br/DocReader/DocReader.aspx>. Acesso em: 12 ago. 2014.

TELEGRAMMAS - Parahyba. A Epoca, Rio de Janeiro, anno II, n. 171, 17 jan. 1913b, p. 02. Disponível em: < http://memoria.bn.br/DocReader/DocReader.aspx>. Acesso em: 12 ago. 2014.

UNIVERSIDADE popular - Uma ideia que toma vulto. Jornal A União, Parahyba, 16 de jan. 1913.

VIEIRA, C. E. História dos Intelectuais: representações, conceitos e teorias. In: CONGRESSO BRASILEIRO DE HISTÓRIA DA EDUCAÇÃO: A EDUCAÇÃO E SEUS SUJEITOS, 4., 2006, Goiânia. Anais... Goiânia: Editora da Universidade Católica de Goiás, 2006. p. 01-10. 


\section{Revista HIISTEYIDIR On-line}

WOLLSTONECRAFT, M. Direito das mulheres e injustiça dos homens. Tradução livre Nísia Floresta Brasileira Augusta. São Paulo: Cortez, 1989.

\section{Notas}

1 Professora do Departamento de Educação Básica (DEBAS) do Centro de Educação (CE) da Universidade Federal da Paraíba (UFPB). Atualmente é doutoranda no Programa de Pós-Graduação em Educação (PPGECE-UFPB) e participante do Grupo de Estudos e Pesquisas em História da Educação - GT Paraíba (HISTEDBR-PB); do Grupo de História da Educação no Nordeste Oitocentista - GHENO (UFPB) e do Grupo de História das Instituições e dos Intelectuais da Educação no Brasil (PUC/SP). Desenvolve pesquisas na área de História da Educação com ênfase em Pensamento Social e Educacional brasileiro, intelectuais e História das Mulheres.

${ }^{2}$ Professora do curso de Pedagogia, Departamento de Habilitações Pedagógicas (DHP) do Centro de Educação (CE) da Universidade Federal da Paraíba (UFPB). Doutora em Educação pelo Programa de Pós-Graduação em Educação (PPGE) da UFPB. Participante do Grupo de Estudos e Pesquisas em História da Educação - GT Paraíba (HISTEDBR-PB); do Grupo de História da Educação no Nordeste Oitocentista - GHENO (UFPB) e do Grupo de História das Instituições e dos Intelectuais da Educação no Brasil (PUC/SP). Realiza estudos e pesquisas na área de Educação, com ênfase em História da Educação, atuando principalmente com os seguintes temas: intelectuais, hermenêutica, política educacional, formação docente e educação infantil.

${ }^{3}$ Doutor em Sociologia pela Universidade Federal de Pernambuco (UFPE). Estágio Pós-Doutoral Sênior no Instituto de Educação, na área de História da Educação, na Universidade de Lisboa (UL), no biênio2015/2016. Professor associado III, na área de Sociologia da Educação, no Departamento de Fundamentação da Educação (Centro de Educação). Professor pesquisador, habilitado a orientar nos cursos de mestrado e doutorado do Programa de Pós-Graduação em Educação (Centro de Educação) da Universidade Federal da Paraíba (UFPB), na linha de História da Educação, desde 2008. Coordenador da linha de História da Educação no Programa de Pós-Graduação em Educação (PPGE-UFPB) no biênio2016-2018. Desenvolve pesquisas sobre História Intelectual e dos Intelectuais, História Conceitual, Teoria e História da Educação. Lidera o Diretório no Cnpq do Grupo de Estudos e Pesquisas História, Sociedade e Educação no Brasil (Histedbr-GT Paraíba), atuando na Linha História Intelectual e dos Intelectuais, (Auto) Biografias e Estudos de Gênero, além de integrar também o Grupo de Pesquisa História da Educação no Nordeste Oitocentista (Gheno) e o Grupo História das Instituições e dos Intelectuais da Educação no Brasil.

${ }^{4}$ Berta Lurzt lutava em favor da emancipação feminina através do voto, tido como forma de regeneração moral e política. (SOIHET, 2000; MENDES, 2008).

${ }^{5}$ Segundo Rago (1985) e Mendes (2008), mesmo Maria Lacerda de Moura não se denominando anarquista, preferindo ser identificada apenas como individualista, se aproximava desse movimento através das bandeiras políticas as quais levantava como a educação feminina, o anticlericalismo, a luta contra o fascismo e contra a guerra. Além disso, Maria Lacerda de Moura escreveu livros, artigos e proferiu conferências, tratando da emancipação intelectual da mulher e do amor livre.

${ }^{6}$ Essa expressão retoma ao artigo publicado, em 17 de abril de 1913, pelo jornal parahybano A imprensa, órgão vinculado a igreja Católica que ao tratar do tema feminismo utilizou essa expressão para abordar o assunto. (MARTINS, 1976; 1978). Como também ao texto publicado na revista O Educador, em 26 de junho de 1922, pela sufragista parahybana, Analice Caldas, companheira de Catharina Moura na fundação, em 1933, da Associação Parahybana pelo Progresso Feminino. (ABRANTES, 2010; FRAGOSO, 2011).

${ }^{7}$ Dentro das medidas do projeto de modernidade para o estado, Castro Pinto trouxe de volta para a Parahyba o intelectual, seu conterrâneo de Mamanguape, Carlos Dias Fernandes para dirigir o jornal A União e a imprensa oficial. Sobre a atuação desse intelectual no jornal ver: GALVÍNCIO, 2013.

${ }^{8}$ Ao fazer a discussão em 1907, Castro Pinto a entendeu as universidades populares como uma forma de afastar o povo de teorias que considerava perigosas para a nação como o anarquismo. (ESPINDOLA, 2012).

${ }^{9}$ Essa notícia foi vinculada no jornal A União do dia primeiro de fevereiro.

${ }^{10}$ Aguiar (1999) não faz menção à duração dos cursos da Universidade carioca, portanto não há como fazermos comparações com a parahybana. 
11 O prêmio da viagem para Europa foi instituído em 1901, por meio de um concurso com os melhores alunos da turma. (ESPINDOLA, 2017).

${ }^{12}$ Eudésia Viera membro do IHPG, diplomada professora, em 1911, e depois se formou médica, em 1934, teve seu livro didático, Pontos de História do Brasil, adotado pelas escolas públicas do estado.

${ }^{13}$ Segundo a autora, Telles (2011, p. 405), não foi possível identificar a biografia dessas mulheres, mas se sabe que as mesmas “[...] estavam a par das ideias européias sobre a posição da mulher na sociedade e de suas reivindicações de igualdade".

14 As discussões em torno do voto feminino seguiram toda a década de 20, do século passado, sendo instituído em 1932 e confirmado pela Constituinte de 1934. (SOIHET, 2000).

Submetido em: 09/02/2018

Aprovado em: 02/04/2018

Publicado em: 11/04/2018 